\title{
ScITECH: An approach in teaching Science Technology Society (STS) course in higher education
}

Espinosa, Ken Paul M.

Colegio De San Juan De Letran Manila, Philippines (kenpaul.espinosa@letran.edu.ph)

Mangali, Glen R. $\bowtie$

Colegio De San Juan De Letran Manila, Philippines (glen.mangali@letran.edu.ph)

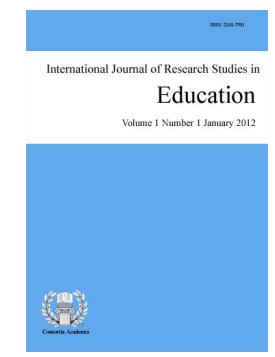

ISSN: 2243-7703 Online ISSN: 2243-7711

OPEN ACCESS

\section{Abstract}

This research determined the effectiveness of ScITECH (Student-Faculty Connection, Individual Difference, Technological Integration, Essentials, Collaborative Learning, and Higher-Order Thinking Skills) Teaching Approach in improving the delivery of instruction in Science, Technology, and Society (STS). The ScITECH teaching approach was developed from the learning interests of college students and focus group discussion. The researchers used a sequential mixed method. A total of three hundred eleven (311) students participated in the study enrolled in the first semester of School Year 2018-2020. An Automated Students' Instructional Survey (ASIS) was given to both groups at end of their first semester to evaluate the instructional competence of the faculty. The gathered data revealed that students appreciated the course and the instructional competence of the faculty using ScITEC when compared to traditional teaching. There is a significant difference in the academic scores of students when two groups were compared. Furthermore, ScITECH can be an effective approach in teaching STS and can improve the teaching skills of teachers and learning interests of the students.

Keywords: teaching approach; students' interests; higher education; STS 


\section{ScITECH: An approach in teaching Science Technology Society (STS) course in higher education}

\section{Introduction}

Science and technology have been quickly changing based on expanding relevance to society. Teaching science and technology in relation to society is getting more challenging and more complex nowadays. Faculty must understand on how students can be guided and supported with their diverse interests, skills, and experiences. A study in Australia conducted by Tedman in 2005 revealed that there was a significant number of faculty members who had limited in understanding science, technology and society (STS) issues in relation to delivering instruction to students. An investigation also revealed that one of the challenges identified was putting STS education into practice in a way that students must understand the relation of science and technology to societal interface (Mansour, 2007; Pederson \& Totten, 2001). In view of this, it showed on the 2015 Program for International Students Assessment (PISA) results that 40 out of 70 countries gained lower score on science achievement (OECD, 2016).

In the Philippines, research shows that the quality of learning in science education in many institutions is correlated on how science teachers greatly influence learners. Students' interests are directly linked on the quality of instructional skills and learning related activities provided and delivered by their science faculty (SEI-DOST \& UP NISMED, 2011; Bozack, 2008). It was also found out that creation of positive environment towards promoting caring student-teacher connection has been missing (Rascoe \& Atwater, 2005). Moreover, lack of qualified science faculty in the Philippines in many institutions lead to the practice of assigning faculty to teach science subject despite of their limited background (Amirshokoohi, 2010). Likewise, recent studies found out that teachers handling general education science subjects are mostly non-science majors (UP NISMED, 2003).

One of the challenges of learning science is often referred to students' inability to understand the science problem given by the faculty that is different from how science is taught in school (Ornek et al., 2008; Liston et al., 2006). Teaching science in this situation can lead to vagueness and confusion to students. Identifying students' interest is one of the key factors in increasing readiness and students' engagement to learn. However, contemporary studies show when students are growing, their interest in science also declines (Dawson, 2000; Bae, 2002; Osborne, 2003; Brophy, 2008; Eccles et al., 1993). Nevertheless, this can be avoided by equipping students with science literacy and bringing closely their needs and latest learning interests in STS towards them as members of progressive technological society (Inzanah et al., 2014).

This study aims to determine the effectiveness of ScITECH (Student-Faculty Connection, Individual Difference, Technological Integration, Essentials, Collaborative Learning, and Higher-Order Thinking Skills) teaching approach in enhancing the instructional skills of the faculty in teaching STS. This action intends to identify factors concerning college students' learning interests that affect teaching-learning process. As Hidi and Harackiewicz (2000) stated that upholding interest can contribute to a more promising and engaging learning experience for the students.

\subsection{Implementation theory}

The emergence of ScITEC teaching approach, which was used in the delivering quality instruction to the college students for the benefit of their interests was anchored from the three (3) theories, namely: the TPACK (Technological Knowledge-TK, Pedagogical Knowledge-PK, and Content Knowledge-CK) framework developed by Mishra and Koehler in 2006; the Multiple Intelligence (M.I.) postulated by Dr. Howard Garner in 1983; and the Revised Bloom's Taxonomy by Anderson and Kratwohl in 2001.

2 Consortia Academia Publishing (A partner of Network of Professional Researchers and Educators) 
The theory of M.I. proposes a major transformation in the way teaching approach has been done. It suggests that faculty must deliver their lessons in a wide variety of ways by means of art activity, group activity, debate, simulation, game, musical integration, picture analysis, reflection, role play, and many more, because learning happens best when students are interested on the teaching approach given by their respective faculty. Furthermore, this also provides opportunity for the students to learn in their unique minds and skills which promotes a positive learning environment as a whole.

The Revised Bloom's Taxonomy creates an opportunity for the faculty to deliver the topics from the most basic up to the more complex manners, or from remembering to creating, either on teaching or in questioning. It creates a positive student-faculty connection in way students appreciate the process of learning. Today, learning is defined as the results of learners' activities which focuses on the higher-order thinking skills. These focus on following: (1) breaking information into parts to explore understanding and relationships of ideas and concepts; (2) justifying a decision or course of action, and generating new ideas; and (3) products or ways of viewing things, which are target outcomes of 21 st century skills. These can be acquired through process of delivering instruction from simple (remembering) to complex (creating).

The TPACK framework offers a productive innovative approach wherein the faculty can handle educational dilemmas on how content is being taught in the classroom and how this content can be technologically imparted in order to enhance students' learning experience. From these three (3) theories and learning interests of the college students, the researchers developed an approach called ScITECH teaching approach, which has a particular intention to improve the instructional skills of a faculty in teaching STS.

Following the action research paradigm, this research adhered to the System Model of Action-Research Process:

The first stage of action research which is the input of the study contains planning in improving teaching approach in STS based on college students' learning interest. Suggestions and ideas were collated from students during the first semester of S.Y. 2018-2019. Learning interests were asked by the faculty and fully discussed by the college students during focus group discussion. This was done to identify how may the faculty boosts their readiness to learn and to deepen their engagement. The second stage is the transformation stage that includes action relating in the implementation of ScITECH teaching approach. The ScITECH teaching approach emerged from the planning stage. The implementation had begun during the first semester of S.Y. 2019-2020. The participants were taught in two different teaching approaches. The ScITECH teaching approach was applied on the experimental group last first semester of S.Y. 2019-2020 while regular teaching method was administered to the control group during the first semester of S.Y. 2018-2019. The third stage of action research contains the output or results phase. An Automated Students' Instructional Survey (ASIS) was given to both groups at end of their first semester to evaluate the instructional competence of the faculty. This is intended to assess if the ScITECH teaching approach may continuously improve the faculty teaching approach and if this is an effective instructional key that they may able to use significantly to improve their teaching skills in relation to the learning interests of the college students. This action-research is a cyclical process of change which begins with a series of planning actions resulting from corrective actions steps taken from the first and second stages. Adjustment can be made via feedback on loops A, B, and C.

\section{Materials and methods}

\subsection{Research design}

The researchers used a sequential mixed method. The ScITECH teaching approach was designed based on the learning interests of college students who were enrolled in STS. Ideas and suggestions of participants were based on their experiences on the teaching-learning process they had encountered during their academic years in school. The researchers codified the common themes reflected on the focus group discussion. It showed that (1) 
focusing on the essential topics, (2) technological integration, (3) collaborative learning, (4) positive student-faculty connections, (5) individual differences and (6) an opportunity for the students to generate new ideas were the approaches that students had learned and enjoyed most. The particular intention of the ScITECH teaching approach is to improve the instructional skills of the college faculty in teaching STS. The "Sc" stands for Student-Faculty Connections, wherein promoting positive connections to students leads to intrinsic motivation and inspiration for them to learn more. The "I" stands for Individual Differences, through this teaching approach, students learn effectively and efficiently for the reason that the activities that they had were the field of their interests. The " $T$ " stands for Technological Integration, wherein the students become further engaged as they were more driven and familiar in using and handling such technologies in the teaching-learning process. It also helped the researcher to present the lessons in convenient and creative ways. The "E" stands for Essentials, focusing on the essentials prevent vagueness and confusion to the students. It is also a way of simplifying complex topics with the intention of preventing students' misinterpretations. The " $\mathrm{C}$ " stands for Collaborative Learning, this promotes collaboration among college students that leads to effective communication, creativity, and critical thinking, which are the target outcomes of 21 st century education. Lastly, The "H" stands for Higher-Order Thinking Skills, which provides an opportunity for the students to generate new ideas by asking them questions and giving them hands-on-tasks that require analyzation, evaluation, and creation. However, for this to become effective, lower-thinking skills must strongly acquire first by the students for them to have a good foundation of the topics. This can be achieved also by focusing on the essential concepts.

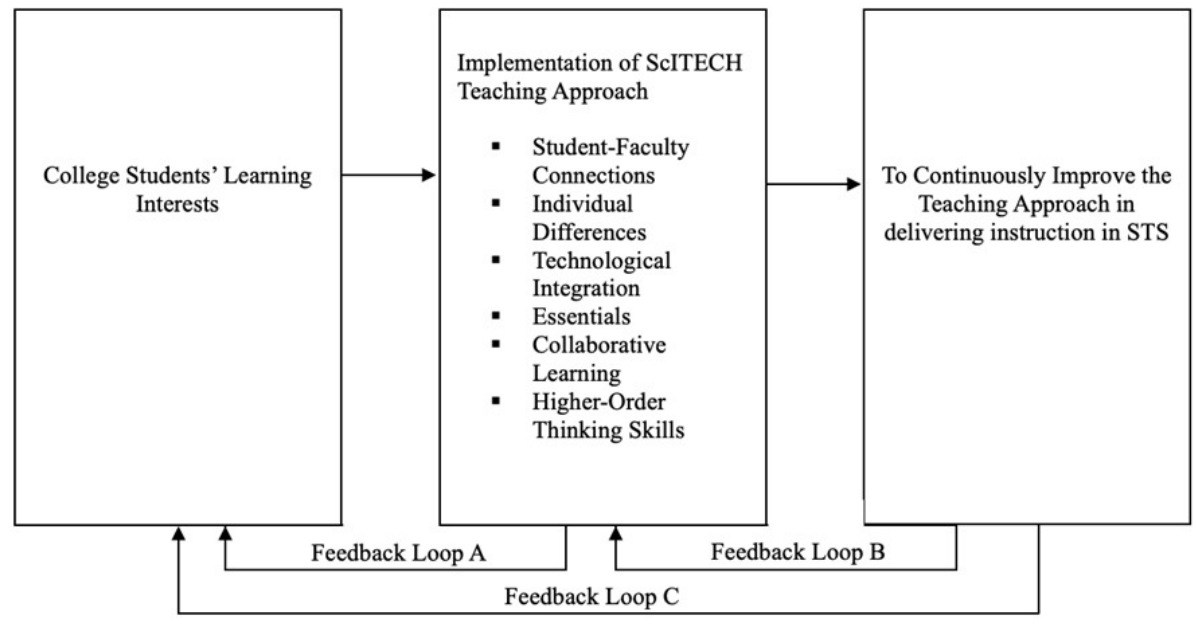

Figure 1. System model of action-research process of the study.

\subsection{Research sampling/locale/participants}

The college students from a private institution in Manila City, Philippines enrolled in STS course on the first semester of S.Y. 2018-2019 and 2019-2020 were involved in the study. A total of one hundred twenty-three (123) college students from the untreated group and one hundred eighty-eight (188) from the treatment group participated in the study.

\subsection{Procedure}

The research instrument used in gathering data was an institutional-made electronic survey questionnaire based on the institutional automated students' instructional survey. This was subjected to construct and content validation by the experts. Prior to actual conduct of the study, the outcomes of the pilot study were subjected to reliability testing using Cronbach Alpha. The beginning of data collection was happened at the end of the first semester of S.Y. 2018-2020 and first semester of S.Y. 2019-2020.

\subsection{Ethical consideration}

The study observed the principle of confidentiality which refers to the researcher's responsibility to protect

4 Consortia Academia Publishing (A partner of Network of Professional Researchers and Educators) 
all data gathered within the scope of the study from being divulged to others and safeguard the information gathered from the participants. The principle of anonymity which refers to the act of keeping individuals nameless in relation to their participation in a study was also applied. Moreover, the principle of self-determination was implemented during the conduct of the study. Participants control their own decision and is free to participate or refuse in the study. Participants involved in the study were protected from any form of influence.

\subsection{Data analysis}

Weighted Mean was used to get the overall rating of the degree of instructional competence of the faculty before and after the implementation of ScITECH teaching approach as assessed by two groups of participants. Furthermore, t-Test: Two-Sample Assuming Equal Variances was used to test the difference in the assessment on the degree of instructional competence of the faculty before and after the implementation of ScITECH teaching approach.

\section{Results and discussion}

This section presents the result and discussion based on how the research questions were presented in the introduction.

\subsection{ScITECH teaching approach}

The table 1 shows that the two groups of participants strongly agreed that the faculty showed an excellent instructional skill in teaching STS. It can be gleaned on the gathered data of the control group, it showed that effective motivation to develop interest of students towards the course (item no. 3) obtained the highest instructional skill of the faculty, while learning activities that integrate the positive character and strengthen the institutional core values (item no. 11) was the least mastered skill showed on the ASIS when students assessed their professor last first semester of S.Y. 2018-2019. On the other hand, after the implementation of ScITECH teaching approach to the treatment group, it revealed that the professor obtained a 4.83 grand mean on the instructional competence. In fact, it showed that on all items, there was an evident improvement in the instructional skills of the faculty as compared to previous evaluation last S.Y. 2018-2019. This proved that ScITECH teaching approach is an effective way that the college faculty may use this approach significantly to continuously improve their instructional skills in relation to the learning interests of the college students. According to Khare (2018) to make education reachable, entertaining, meaningful and relevant, student's readiness and interest must be catered as integral parts of student-centered teaching approach. In addition, students' interest is a powerful motivational tool that energizes learning and processes information effectively (Renninger \& Hidi, 2016). Providing students opportunities to generate new ideas, focusing on essentials to avoid vagueness, identifying strengths, and making the classroom conducive to learning through positive faculty-student connection can promote interest and as well as learning.

The most improved skill displayed by the faculty was item no. 11, which is connected to the positive student-faculty connection and collaborative learning of ScITEC teaching approach. Through positive student-teacher connection, it created a positive classroom environment conducive to positive learning activities. This was intended for the college students to also inculcate the core values of their respective institution. It revealed that item no. 1 was the most outstanding skill showed by the faculty. It is significant for the students to understand the rationale, objectives and scope of the subject in order for instruction to become effective. This can also be a way for the students to recognize that this can be an essential help for them to fully apprehend key ideas and concepts of the lessons. Helping students to find meaning and value of the subject course is a route in capturing and sustaining students' interest (Harackiewicz \& Hulleman, 2010). Furthermore, if students are interested in a way that faculty teaches the lessons, it holds so much influence for the students to engage willingly to spend more time learning (McCarthy, 2014). 
Table 1

Faculty Evaluation Results Before and After the Administration of ScITECH Teaching Approach to Both Groups

Instructional Competence Rubric

\begin{tabular}{|c|c|c|c|}
\hline \multicolumn{2}{|c|}{$\begin{array}{l}\text { Untreated Group } \\
\text { S.Y. 2018-2019 }\end{array}$} & \multicolumn{2}{|c|}{$\begin{array}{l}\text { Treatment Group } \\
\text { S.Y. 2019-2020 }\end{array}$} \\
\hline WM & Q. I & WM & Q. I \\
\hline 4.74 & E & 4.88 & E \\
\hline 4.70 & E & 4.84 & E \\
\hline 4.77 & E & 4.84 & $\mathrm{E}$ \\
\hline 4.71 & E & 4.82 & E \\
\hline 4.74 & $\mathrm{E}$ & 4.84 & $\mathrm{E}$ \\
\hline 4.70 & E & 4.84 & E \\
\hline 4.70 & $\mathrm{E}$ & 4.84 & $\mathrm{E}$ \\
\hline 4.70 & $\mathrm{E}$ & 4.82 & $\mathrm{E}$ \\
\hline 4.71 & E & 4.84 & E \\
\hline 4.71 & $\mathrm{E}$ & 4.81 & $\mathrm{E}$ \\
\hline 4.60 & $\mathrm{E}$ & 4.82 & $\mathrm{E}$ \\
\hline 4.70 & $\mathrm{E}$ & 4.81 & $\mathrm{E}$ \\
\hline 4.71 & $\mathrm{E}$ & 4.83 & $\mathrm{E}$ \\
\hline 4.71 & $\mathrm{E}$ & 4.79 & $\mathrm{E}$ \\
\hline 4.72 & $\mathrm{E}$ & 4.83 & $\mathrm{E}$ \\
\hline 4.71 & $\mathbf{E}$ & 4.83 & $\mathbf{E}$ \\
\hline
\end{tabular}

1. Makes us students understand the rationale, objectives and scope of the subject/course.

2. Considers our prior knowledge and its clear connection with the current lesson.

3. Uses an effective motivation to develop our interest to the subject.

4. Employs a variety of teaching techniques and approaches appropriate to us and the subject matter.

5. Places/Puts us in purposive and interactive learning engagement time.

6. Engages us in critical discussion activities that develop our critical and creative thinking as well as our problem-solving skills.

7. Demonstrates mastery of the lesson and facilitates its learning.

8. Provides clear and specific lesson explanations using real life examples.

9. Employs effective and appropriate questioning techniques that stimulate our higher order thinking skills.

10. Leads us to discover from the lessons, new and innovative ideas.

11. Creates learning activities that integrate the positive character and strengthen the institutional core values.

12. Provides us opportunities for both collaborative and independent learning.

13. Utilizes appropriate digital tools and applications in learning activities.

14. Enables us to make meaningful connections of the lessons with life's realities.

15. Engages us with diverse activities that promote acquisition, meaning making and transfer of learning.

GRAND MEAN

atisfactory - VS); 2:50-3.49 (Satisfactory Legend: 4:50-5:00 (Excellent - E); 3:50-4.49 (Very Satisfactory - VS);
S); 1:50-2.49 (Needs Improvement - NE); 1.00-1.49 (Poor - P)

3.2 Significant Difference in the Assessment of Two Groups of Participants Before and After the Implementation of ScITECH Teaching Approach

The results of the study show that there is a sufficient evidence in rejecting the null hypothesis, testing it at a level of significance of 5\%. It showed that there is a significant difference in the academic scores of control (traditional approach) and experimental groups (ScITECH teaching approach) of participants; $\mathrm{t}(28)=2.05, p=$ 4.46639E-12, before and after the implementation of ScITEC teaching approach to the college students. These results suggest that ScITECH can be an effective approach in teaching the course Science Technology and Society (STS) which can improve the teaching skills of the faculty and learning interests of the students. The intervention is evidently showed its effectiveness in teaching STS.

6 Consortia Academia Publishing (A partner of Network of Professional Researchers and Educators) 
The researchers tried to codify the common theme reflected on the ASIS comment sections that deliberately placed after the set of quantitative statements. The gathered data revealed the following general findings, such as: (1) the college students appreciated how the faculty turned and relate the lessons into real life situation, which were easier for them to comprehend; (2) the college students also commended on the way the faculty communicated to them in a way they can understand the lessons and instructions; (3) the college students had seen how the faculty exerted efforts by showing mastery of the subject matter through providing different activities and maintaining a well-equipped manner; (4) the college students also observed how knowledgeable and well-skilled the faculty was, which had been suitable for the subject matter, STS; (5) the college students witnessed how the faculty maintained a classroom environment desirable to effective learning; (6) the college students mentioned the methods of providing mnemonics and acronyms were very helpful for them, especially in the teaching-learning process; and lastly (7) the students commended the faculty for regularly giving a positive and helpful feedback on the class performance, which motivated them to learn more. In addition to this, it was found out that providing opportunities to the students to develop thinking skills to take active roles in studying STS would give them positivity for a better future (Tedman, 2005). When a faculty focuses more on essentials differentiating by student's interest, it helps remove the obstacle in learning (Walkington \& Bernacki, 2014). It suggests that if the students are interested, it leads to readiness which boost their engagement to learn more and deepen their understanding towards the lesson (McCarthy, 2014).

\subsection{Implication of study}

Based on the findings from this study, the following implications were drawn:

The study implies that teaching approaches such as ScITECH can help learners to be engaged in the evaluation on how teachers deliver the lesson which is beneficial in the teaching and learning process. It can serve as alternative approach in teaching collegiate students not just in STS but also in other courses. The study opens opportunity to revisit the current practices in teaching science such as STS. In the collegiate level where lecture is one of the common strategies in teaching, current practices in various courses and colleges must be evaluated to assess if the implemented teaching strategies and approaches in teaching is deemed necessary or appropriate to the leaners.

The study shows the significance of feed-backing system. Teachers and students should work together as a team to serve one another in the fulfilment of the learning in academic environment. It is necessary that feed-backing should be seen as a positive process rather than a negative practice in the academe. Capacity building for teachers should be done on a regular basis to equip beginning, experienced and season teachers in teaching their assigned courses.

\section{References}

Amirshokoohi, A. (2010). Preservice elementary teachers' understanding and attitude toward STS and environmental education: A field study. Science Educator, 19(1), 56-63.

Anderson, L.W., \& Krathwohl, D. R. (2001). A taxonomy for learning, teaching, and assessing (Abridged ed.). Allyn and Bacon.

Bae, M. J. (2002). An analysis of the psychological structure if 'learned helplessness': A case study. Seoul National University Press.

Bozack, A. R. (2008). Growing new teachers: The relationship among professional development, efficacy beliefs, and classroom practices. http://Arizona.openrepository.com/Arizona/bitstream/10150/195080/1/azu_etd_2628_sip1_m/pdf

Brophy, J. (2008). Developing students' appreciation for what is taught in school. Educational Psychologist, 43, 132-141. https://doi.org/10.1080/00461520701756511

Dawson, C. (2000). Upper primary boys' and girls' interests in science: have they change since 1980 ? International Journal of Science Education, 22(6), 557-570. https://doi.org/10.1080/095006900289660 
Espinosa, K. P. M., \& Mangali, G. R.

Eccles, J. S., Midgley, C., Wigfield, A., Buchanan, C. M., Reuman, D., Flanagan, C., \& Mac Iver, D., (1993). Development during adolescence: The impact of stage-environment fit on young adolescents' experiences in schools and families. American Psychologist, 48, 90-101. https://doi.org/10.1037/0003-066X.48.2.90

Gardner, H. (1993). Frames of mind: The theory of multiple intelligences. Basic Books.

Harackiewicz, J. M., \& Hulleman, C. S. (2010). The importance of interest: The role of achievement goals and task values in promoting the development of interest. Social \& Personality Psychology Compass, 4, 42-52. https://doi.org/10.1111/j.1751-9004.2009.00207.x

Hidi, S., \& Harackiewicz, J. M. (2000). Motivating the academically unmotivated: A critical issue for the 21 st century. Review of Educational Research, 79, 151-179. https://doi.org/10.2307/1170660

Inzanah, I. M., \& Widodo, W. (2014). Development of 2013 curriculum-based natural science learning tools to train junior high school students' science literacy [Pengembangan Perangkat Pembelajaran IPA Berbasis Kurikulum 2013 untuk Melatih Literasi Sains Siswa SMP]. UNESA Postgraduate Science Education, 4(1), 459-467. https://doi.org/10.26740/jpps.v4n1.p459-467

Khare, K. (2018). Making learning meaningful and accessible. A medium corporation. https://medium.com/a-teachers-hat/making-learning-meaningful-and-accessible-63e51a3052a6

Liston, D., Whitcomb, J., \& Borko, H. (2006). Too little or too much: Teacher preparation and the first years of teaching. Journal of Teacher Education, 57, 351-358. https://doi.org/10.1177/0022487106291976

Mansour, N. (2007). Challenges to STS education: Implications for science teacher education. Bulletin of Science, Technology and Society, 27. https://doi.org/10.1177/0270467607308286

McCarthy, J. (2014). Learners interest matters: Strategies for empowering students' choice. George Lucas Educational Foundation. Edutopia. https://www.edutopia.org/blog/differentiated-instruction-learner-interest-matters-john-mccarthy

Mishra, P., \& Koehler, M. J. (2006). Technological pedagogical content knowledge: A framework for integrating technology in teachers' knowledge. Teachers College Record, 108(6), 1017-1054. https://doi.org/10.1111/j.1467-9620.2006.00684.x

OECD [Organization for Economic Co-operation and Development]. (2016). PISA 2015 results. What students know and can do student performance in mathematics, reading and science (Vol. 1). OECD Publishing.

Ornek, F., Robinson, W. R., \& Haugan, M. P. (2008). What make physics difficulty? International Journal of Environmental \& Science Education, 30(1), 30-34.

Osborne, J. (2003). Attitudes towards science: A review of the literature and its implications. International Journal of Science Education, 25(9), 1049-1079. https://doi.org/10.1080/0950069032000032199

Pederson, J. E., \& Totten, S. (2001). Beliefs of science teachers toward the teaching of science, /technology/social issues: Are we addressing National Standards? Bulletin of Science Technology \& Society, 21(5), 376-393. https://doi.org/10.1177/027046760102100507

Rascoe, B., \& Atwater, M. M. (2005). Black males' self-perception of academic ability and gifted potential in advanced science classes. Journal of Research in Science Teaching, 42, 888-911. https://doi.org/10.1002/tea.20077

Renninger, K. A., \& Hindi, S. (2016). The power of interest for motivation and engagement. Routledge. https://doi.org/10.4324/9781315771045

SEI-DOST, \& UP NISMED. (2011). Framework for Philippine science teacher education. SEI-DOST \& UP NISMED.

Tedman, D. K. (2005). Science teachers' views on science, technology and society issues. Applied Rasch Measurement: A book of exemplars. Education in the Asia-Pacific Region: Issues, Concerns and Prospects (Vol. 4). Springer.

UP NISMED. (2003). Supervision of science and mathematics teaching. UP NISMED Press.

Walkington, C. A., \& Bernacki, M. L. (2014). Motivating students by "personalizing" learning around individual interest: A consideration of theory, design, and implementation issues. Advances in Motivation and Achievement, 18, 139-176. https://doi.org/10.1108/S0749-742320140000018004

8 Consortia Academia Publishing (A partner of Network of Professional Researchers and Educators) 